\title{
Aktivitas Anticestoda In Vitro Metabolit Sekunder Daun Miana (Coleus blumei. Benth) terhadap Cacing Hymenolepis microstoma
}

\section{In Vitro Anticestode Activity of Secondary Metabolite of Coleus blumei. Benth Leaves on Hymenolepis microstoma}

\author{
Yusuf Ridwan $^{1 *}$ Fadjar Satrija $^{1}$, Ekowati Handharyani $^{2}$ \\ ${ }^{1}$ Divisi Parasitologi dan Entomologi Kesehatan, \\ Departemen Ilmu Penyakit Hewan dan Kesehatan Masyarakat Veteriner, \\ Fakultas Kedokteran Hewan, Institut Pertanian Bogor \\ ${ }^{2}$ Divisi Patologi, Departemen Klinik, Reproduksi, dan Patologi, \\ Fakultas Kedokteran Hewan, Institut Pertanian Bogor \\ Jalan Agatis, Kampus IPB Darmaga, Bogor, 16680 \\ *Corresponding author: yusufridwan67@yahoo.com
}

\begin{abstract}
Abstrak
Penelitian ini untuk mengetahui golongan senyawa metabolit sekunder dari ekstrak daun miana (Coleus blumei. Benth) yang memiliki aktivitas anticestoda. Daun miana kering diekstraksi dengan metode yang sesuai untuk mendapatkan golongan senyawa metabolit sekunder alkaloid, flavonoid, tanin, dan steroid. Aktivitas anticestoda diukur dengan menghitung waktu kematian cacing Hymenolepis microstoma pada setiap golongan metabolit sekunder konsentrasi 10\%. Hasil penelitian menunjukkan tanin memiliki aktivitas anticestoda yang kuat yang tidak berbeda dengan praziquatel sebagai anthelmintik komersial. Akivitas anticestoda flavonoid mirip dengan tanin akan tetapi aktivitasnya masih dibawah praziquatel. Alkaloid dan steroid memiliki aktivitas anticestoda yang lebih rendah dibandingkan dengan tanin dan flavonoid. Hasil penelitian ini membuktikan bahwa tanin sebagai senyawa metabolit sekunder yang paling aktif sebagai anticestoda dibandingkan flavonoid, alkaloid, dan steroid.
\end{abstract}

Kata kunci: daun miana, metabolit sekunder, anticestoda, Hymenolepis microstoma

\begin{abstract}
The aim of this study was to determine secondary metabolite of Coleus blumei. Benth leaves which has anticestode activity. Coleus blumei. Benth leaves were extracted which appropriate methods to obtain alkaloid, flavonoid, tannin, and steroid. The anticestode activities of secondary metabolite obtained were evaluated in vitro. Anticestode activity was evaluated with an assay using Hymenopepis microstoma in 10\% concentration of metabolite secondary by determination of mortality time. The result of this study showed tannin performed strong anthelmintic activity with no different with praziquatel as commercial anthelmintic product. Aticestode activity flavonoid was similar with tannin but its aticestode activity had lower than commercial anthelmintic. Alkaloid and steroid had lower anticestode activity comparing both tannin and flavonoid. This study revealed that tannin to be a more efficient of biologically active compounds than either flavonoid, alkaloid or steroid.
\end{abstract}

Key words: Coleus blumei. Benth, secondary metabolite, anticestode, Hymenolepis microstoma

Received: 11 November $2019 \quad$ Revised: 9 Desember 2019

Accepted: 2 Januari 2020

\section{PENDAHULUAN}

Metabolit sekunder merupakan golongan senyawa yang memiliki fungsi berbeda dengan metabolit primer. Metabolit sekunder dalam sistem ekologi mengatur interaksi antara tanaman, mikroorganisme, serangga dan hewan. Golongan senyawa metabolit sekunder meliputi alkaloid, flavonoid, tanin, dan steroid dapat berfungsi sebagai alat mempertahankan diri, antinutrisi, atraktan, dan feromon. Senyawa metabolit sekunder berpotensi untuk dikembangkan sebagai obat untuk melawan infeksi pathogen. Sebanyak $40 \%$ obat modern yang ada sekarang berasal dari pengembangan senyawa metabolit sekunder, termasuk 
anthelmintik seperti ivermectin. Miana termasuk tanaman Lamiaceae mempunyai senyawa aktif yang mampu menghambat dan mematikan berbagai organisme. Senyawa aktif yang terkandung dalam sari daun miana mempunyai aktivitas antibakteri (Kusumawati et al. 2014), antinflamasi (Pallete et al. 2017), fungisidal (Karo et al. 2018), imunomodulator (Pakadang et al. 2015), antioksidan (Podungge et al. 2017), dan termasuk anthelmintik (Ridwan et al. 2010 ).

Penelitian aktivitas anticestoda daun miana telah dilakukan dengan menggunakan cacing model dari genus Hymenolepis termasuk $H$. nana dan H. microstoma (He et al. 1992). Simplisia daun miana mampu mengeliminasi cacing pita $H$. nana pada mencit (He et al. 1992; Ridwan dan Ayunina 2007, Ridwan et al. $2010^{\text {a, }}$ b) dan aktivitas anticestoda yang paling kuat terdapat pada varietas dengan warna daun yang lebih gelap (Ridwan dan Ayunina 2007).

Hasil penelitian sebelumnya menunjukkan bahwa aktivitas anticestoda in vitro ekstrak daun miana pada cacing $H$. microstoma menyebabkan kerusakan bagian tegumen dan micotrich H. microstoma (He et al. 1992, Ridwan et al. $2010^{\text {a, b}}$ ). Namun, hasil penelitian secara in vivo menunjukkan kebutuhan jumlah dosis yang cukup besar untuk mengeluarkan cacing pita model H.microstoma (Ridwan et al. 2010 ).

Ekstrak etanol tidak efesien apabila digunakan sebagai obat herbal untuk mengobati cestodosis, oleh karena itu, perlu ditelusuri lebih lanjut golongan senyawa metabolit sekunder mana yang memiliki aktivitas anticestoda. Penelitian ini perlu dilakukan sebagai tahapan mendapatkan suatu senyawa anthelmintik alternatif yang bisa dikembangkan untuk mengendalikan cestodosis pada hewan dan manusia.

\section{METODE PENELITIAN}

\section{Penyiapan daun miana}

Daun Miana yang digunakan dikoleksi dari sekitar Kabupaten Bogor. Daun miana yang telah dikumpulkan dibersihkan, kemudian dipotong menjadi potongan yang kecil menggunakan gunting. Potongan daun miana tersebut kemudian dijemur di bawah sinar matahari selama \pm 2 hari. Daun miana yang sudah kering diblender untuk mendapatkan serbuk daun miana.

\section{Penyiapan cacing $\boldsymbol{H}$. microstoma}

Cacing H. microstoma diperoleh dari mencit donor yang telah diinfeksi. Mencit donor yang positif $H$. microstoma dieutanasia dengan menggunakan Nembutal. Rongga perut mencit dibuka dan organ usus dipisahkan dari bagian tubuh lainnya. Usus dibentangkan di atas meja seksi dan difiksir menggunakan jarum pentul, kemudian dibuka. Cacing pita yang terdapat dalam usus diambil, dikumpulkan, dan disimpan dalam media $\mathrm{NaCl}$ 0,5\% sampai digunakan.

\section{Metode Penelitian \\ Desain Penelitian.}

Metabolit sekunder, yakni tanin, flavonoid, steroid, dan alkaloid diekstraksi dari daun miana dengan metode yang dijelaskan dibawah ini. Keempat golongan senyawa yang diperoleh tersebut kemudian diuji aktivitas anticestoda menggunakan model cacing pita $H$. microstoma secara in vitro.

\section{Ekstraksi Alkaloid.}

Metode ekstraksi yang digunakan untuk mendapatkan alkoloid dilakukan dengan metode Lohombo-Ekomba et al. (2004). Sebanyak 200 gram serbuk daun miana kering diekstraksi dengan metode sokletasi menggunakan pelarut heksan. Ektrak yang diperoleh kemudian disaring. Residu atau ampas yang diperoleh dimaserasi dengan metanol, kemudian disaring. Ekstrak metanol yang diperoleh diatur $\mathrm{pH}$-nya menggunakan asam sitrat ( $\mathrm{pH} 3)$, kemudian dipartisi dengan etil asetat. Fase etil asetat yang diperoleh inilah yang mengandung alkaloid total, kemudian dipekatkan dengan Rotary evaporator EYELA $^{\circledR}$ type $93-1000$.

\section{Ekstraksi Flavonoid.}

Proses ekstraksi untuk mendapatkan flavonoid dilakukan dengan metode yang dijelaskan oleh Andersen dan Markham (2006). Sebanyak 100 gram serbuk daun miana kering dibagi dua. Masing-masing 50 gram miana kering dimaserasi dengan metanol : air (9:1) dan 
metanol : air (50:50) dengan cara maserasi selama 3 x 24 jam. Ekstrak yang diperoleh dari masing-masing pelarut disaring kemudian digabungkan. Ekstrak gabungan selanjutnya dipekatkan dengan Rotary evaporator EYELA ${ }^{\circledR}$ type 93-1000 hingga volumenya berkurang menjadi sepertiga volume semula. Ekstrak selanjutnya dipartisi dalam corong pisah dengan heksana kemudian kloroform untuk menghilangkan senyawa yang kepolarannya rendah seperti lemak, terpena, dan klorofil. Fraksi metanol-air selanjutnya dikeringkan dengan pengering putar untuk mendapatkan ekstrak flavonoid kering.

\section{Ekstraksi Tanin.}

Metode ektraksi untuk mendapatkan tanin dilakukan dengan metode Barrau et al. (2005). Daun miana kering sebanyak 100 gram dimaserasi dengan aseton: air (70:30) yang mengandung asam askorbat selama 3x24 jam kemudian dilakukan penyaringan. Selanjutnya ekstrak aseton-air dipekatkan dengan Rotary evaporator EYELA® type 93-1000. Filtrat yang didapat kemudian dicuci dengan Metilen klorida. Fraksi aseton-air yang didapatkan merupakan ekstrak tanin. Ekstrak dipekatkan menggunakan Rotary evaporator EYELA $®$ type 93-1000.

\section{Ekstraksi Steroid.}

Metode ekstraksi yang digunakan untuk mendapatkan steroid dilakukan dengan metode Bahti et al. (1985). Daun miana kering sebanyak 100 gram dimaserasi dengan metanol selama $3 \mathrm{x}$ 24 jam. Ekstrak yang diperoleh dikeringkan dengan pengering putar. Ekstrak metanol kemudian dihidrolisis dengan $\mathrm{KOH} 10 \%$ (dalam etanol) di atas penangas air $100^{\circ} \mathrm{C}$ selama 3 jam kemudian disaring. Hidrolisat yang diperoleh dikeringkan menggunakan Rotary evaporator EYELA ${ }^{\circledR}$ type 93-1000. Ekstrak yang diperoleh kemudian di maserasi dengan dietil eter. Ekstrak dietil eter yang diperoleh kemudian dicuci berturut-turut dengan $\mathrm{H}_{2} \mathrm{O}, \quad \mathrm{HCl}{ }_{2} \mathrm{~N}, \mathrm{H}_{2} \mathrm{O}$, $\mathrm{NaHCO}_{3}$ jenuh dan $\mathrm{NaCl}$ jenuh. Fase dietil eter yang diperoleh kemudian dikeringkan menggunakan $\mathrm{Na}_{2} \mathrm{SO}_{4}$ anhidrat untuk mendapatkan ekstrak steroid.

\section{Analisis statistik.}

Data waktu mortalitas disajikan dalam bentuk rata-rata dan standar deviasi. Perbedaan nilai rata-rata antara perlakuan dianalisis menggunakan anova dilanjutkan dengan uji Duncan pada tingkat kepercayaan 95\%.

\section{HASIL DAN PEMBAHASAN}

Rendemen metabolit sekunder ekstrak tanin, flavonoid, alkaloid, dan steroid yang diperoleh dari daun miana berbeda-beda. Jumlah rendemen paling banyak diperoleh adalah ekstrak tanin dan flavonoid, sedangkan alkaloid dan steroid sangat sedikit yaitu dibawah 2\% (Tabel 1). Jumlah rendemen dari setiap metabolit ini dipengaruhi oleh kadar setiap jenis metabolit yang terdapat di dalam daun miana. Alkaloid yang terdapat di dalam daun miana sangat kecil, hal ini dapat dilihat dari hasil penelitian sebelumnya yang menunjukkan alkaloid tidak terdeteksi dengan metode kualitatif fitokimia (Ridwan et al. $\left.2010^{\mathrm{b}}\right)$.

Rata-rata waktu kematian cacing H.microstoma yang diinkubasikan dalam media kontrol adalah 14.11 \pm 4.01 (Tabel 2). Waktu kematian H.microstoma kelompok perlakuan lebih cepat dibandingkan kelompok kontrol (p <0.05). Rata-rata waktu kematian $H$. microstoma paling cepat terdapat pada kelompok kontrol obat praziquantel dan ekstrak tanin diikuti flavonoid, steroid, dan alkaloid. Aktivitas anticestoda paling lemah terdapat pada steroid dan alkaloid yang ditandai dengan rata-rata waktu kematian cacing yang lebih lama dibandingkan tanin maupun flavonoid.

Tanaman sebagai makhluk hidup harus mampu mempertahankan diri dari pengganggu yang terdapat dilingkungan. Berbeda dengan makhluk hidup lain seperti hewan, tanaman tidak dapat bergerak untuk menghindari musuh, maka untuk mempertahankan diri tanaman memiliki senyawa kimia yang berfungsi sebagai alat mempertahankan diri. Metabolit sekunder merupakan metabolit yang tidak secara langsung terlibat didalam pertumbuhan atau reproduksi tanaman. Metabolit sekunder di dalam sistem ekologi mengatur interaksi antara tanaman, 
Tabel 1. Rendemen dari isolasi masing-masing metabolit sekunder daun miana

\begin{tabular}{cccc}
\hline Metabolit Sekunder & $\begin{array}{c}\text { Jumlah bahan } \\
\text { kering (gram) }\end{array}$ & $\begin{array}{c}\text { Jumlah yang } \\
\text { diperoleh (gram) }\end{array}$ & $\begin{array}{c}\text { Rendemen } \\
(\boldsymbol{\%})\end{array}$ \\
\hline Tanin & 100 & 18.15 & 18.15 \\
Flavonoid & 100 & 15.05 & 15.05 \\
Alkaloid & 200 & 3.10 & 1.55 \\
Steroid & 100 & 1.05 & 1.05 \\
\hline
\end{tabular}

Tabel 2. Rata-rata waktu kematian H.microstoma dalam masing-masing senyawa metabolit sekunder

\begin{tabular}{cc}
\hline Metabolit & $\begin{array}{c}\text { Rata-rata waktu } \\
\text { kematian cacing (Jam) }\end{array}$ \\
\hline Tanin & $0.83 \pm 0.50^{\mathrm{ab}}$ \\
Flavonoid & $1.83 \pm 0.87^{\mathrm{b}}$ \\
Alkaloid & $5.00 \pm 0.71^{\mathrm{c}}$ \\
Steroid & $4.86 \pm 1.69^{\mathrm{bc}}$ \\
Praziquantel & $0.72 \pm 0.26^{\mathrm{a}}$ \\
Kontrol & $14.11 \pm 4.01^{\mathrm{d}}$ \\
\hline
\end{tabular}

Superskrip yang berbeda menunjukkan perbedaan nyata $(\mathrm{p}<0.05)$

mikroorganisme, serangga dan hewan. Golongan senyawa ini dapat berfungsi mempertahankan diri, antinutrisi, atraktan dan feromon. Fungsi senyawa metabolit sekunder dikembangkan sebagai obat untuk melawan infeksi patogen termasuk infeksi cacing parasit (Maulidya et al. 2017; Yuliana dan Fatmawati 2018).

Daun miana memiliki senyawa metabolit sekunder alkaloid, flavonoid, steroid, saponin, tannin, dan antosianin (Khotimah et al. 2018). Hasil penelitian in vitro membuktikan bahwa tanin, flavonoid, steroid, dan alkaloid dari daun miana memiliki aktivitas anticestoda in vitro dengan kemampuan yang berbeda. Tanin dan flavonoid memiliki aktivitas anticestoda in vitro lebih baik dibandingkan metabolit yang lainnya yaitu steroid dan alkaloid.

Tanin dan flavonoid merupakan senyawa turunan fenol yang banyak digunakan sebagai antiparasit (Hidayah 2016; Purwanti et al. 2012). Anthelmintik komersial termasuk senyawa fenol seperti niclosamid, oksiklosanid, dan bitionol merupakan anthelmintik yang bekerja pada cacing cestoda. Senyawa flavonoid dari tanaman telah diteliti memiliki aktivitas anthelmintik seperti tanaman Rhaphidophora pinnata (L.) Schott (Masrifa et al. 2018) dan flavon (2-phenyl cromone) (Lee et al. 2008) yang memiliki aktivitas anthelmintik terhadap nematoda.
Senyawa Artemisinin aktif terhadap protoscolex dan metacestoda Echinococcus (Spicher et al. 2008). Tanaman yang kaya tanin mampu menurunkan jumlah telur per gram (TPG) feses dan jumlah cacing terutama nematoda (Ji et al. 2012).

Spesies Coleus telah diketahui mengandung senyawa turunan fenol yaitu polifenol tanin dan flavonoid (Darwis et al. 2013). Fenol bersifat germisidal karena dalam konsentrasi tinggi menyebabkan koagulasi dan presipitasi protein, sedangkan dalam konsentrasi rendah menyebabkan denaturasi protein tanpa koagulasi (Nadhilla 2014). Bagian luar tubuh cacing pita terdiri dari tegumen yang kaya dengan mikrovili dan berfungsi untuk penyerapan makanan. Akibatnya fenol yang berkontak dengan tubuh cacing pita, akan cepat diserap dan menyebabkan denaturasi protein dalam jaringan cacing sehingga menyebabkan kematian cacing. Senyawa flavonoid seperti Artemisinin aktif terhadap protoscolex dan metacestoda Echinococcus (Spicher et al. 2008). Artemisinin dapat meningkatkan radikal bebas in vitro dengan merusak membran sel (Meshnick et al. 1989). Senyawa genisten merupakan flavonoid dari tanaman dan memiliki aktivitas metacestodasidal in vitro dengan mempengaruhi 
metabolisme glikogen (Tandon et al. 2003) pada cacing cestoda Raillietina echinobothrida.

Tanaman yang mengandung tanin telah dipertimbangkan memiliki potensi untuk pengendalian parasit cacing. Tanin telah dikenal memiliki aktivitas anthelmintik terutama sebagai antinematoda. Beberapa penelitian menunjukkan tanaman yang mengadung tanin secara efektif mampu melawan cacing gastrointestinal (Widiarso et al. 2017). Mekanisme tanaman yang mengandung tanin melawan parasit belum diketahui secara pasti, walaupun demikian diduga tanin mampu mempengaruhi parasit baik melalui efek langsung maupun tidak langsung.

Pengaruh langsung dimediasi melalui interaksi tanin dan parasit yang pada akhirnya mempengaruhi fungsi fisiologi parasit. Molan et al. (2000) memperlihatkan condensed tannin yang diperoleh dari beberapa tanaman menurunkan motilitas dan kemampuan migrasi $\mathrm{L}_{3}$ nematoda. Tanin juga dapat memperlambat proses pelepasan kutikula (exshetment) $\mathrm{L}_{3}$ melalui penghambatan enzim yang berperan dalam proses pelepasan kutila $\mathrm{L}_{3}$ (Brunet et al. 2007). Pengaruh tanin pada pelepasan kutikula larva nematoda berhubungan dengan monomer prodelphinidin dan turunan galloyl (Brunet dan Hoste 2006). Aktivitas hambatan pelepasan kutikula berkaitan dengan jumlah gugus hidroksi, berat molekul dan adanya gugus hidroksi pada R3, yang merupakan ciri unit dari prodelpinidin. Kehadiran gugus $\mathrm{OH}$ dalam jumlah besar pada struktur flavan-3-ol akan mendukung ikatan hidrogen dengan protein dari larva. Lebih jauh lagi adanya gallate diduga juga terlibat dalam interaksi hidrofobik (PoncetLegrand et al. 2006).

Kemampuan tanin dalam membunuh cestoda pada pengujian secara in vitro masih perlu dibuktikan secara in vivo mengingat banyak sekali faktor yang berpengaruh dalam aktivitas biologi di dalam tubuh. Perbedaan kondisi antara in vivo dan in vitro seperti adanya biotransformasi, metabolisme, interaksi dengan makanan, dan penyerapan akan mempengaruhi aktivitas biologinya didalam tubuh. Sebagai suatu sediaan obat yang diberikan secara peroral harus mampu melewati berbagai barier fisik maupun kimia didalam saluran pencernaan sebelum sampai pada target agen penyakit. Berbagai reaksi enzimatik di dalam mulut, lambung dan usus bisa saja membuat tanin tidak aktif, terjadi pemecahan senyawa aktif dan terjadi transformasi senyawa yang dapat merubah kemampuan tanin untuk membunuh cestoda. Pengujian untuk mengetahui efikasi tanin sebagai anticestoda perlu dilakukan.

\section{KESIMPULAN}

Tanin dan flavonoid memiliki jumlah rendemen cukup besar masing-masing 18.15 dan $15.04 \%$, sedangkan rendemen alkaloid dan steroid diperoleh sangat sedikit masing-masing 1.55 dan $1.05 \%$. Ekstrak metabolit sekunder tanin, flavonoid, alkoloid, dan steroid memiliki aktivitas anthelmintik terhadap cacing model $H$. microstoma. Aktivitas anthelmintik paling kuat terdapat pada ekstrak tanin diikuti ekstrak flavonoid, sedangkan alkaloid dan steroid memiliki aktivitas lebih lemah.

\section{UCAPAN TERIMA KASIH}

Kami mengucapkan terima kasih kepada Pusat Studi Biofarmaka, Lembaga Penelitian dan Pengabdian kepada Masyarakat Institut Pertanian Bogor (LPPM IPB) yang telah membantu dalam proses ekstrak metabolit sekunder daun miana.

\section{DAFTAR PUSTAKA}

Andersen, O.M., Markham, K.R. 2006. Flavonoid: Chemistry, Biochemistry, and Applications. Taylor and Francis Group. United States of America.

Bahti, H.H., Tjokronegoro, R., Dimyati, Y.A. 1985. Isolasi dan Identifikasi SenyawaSenyawa Steroid dan Senyawa-Senyawa yang Bertalian dengannya serta SenyawaSenyawa Alkaloid dari Daun Kamboja. Laporan Penelitian, FMIPA. Universitas Padjadjaran. 
Barrau, E., Fabre, N., Fouraste, I., Hoste, H. 2005. Effect of bioactive compounds from sainfoin (Onobrychis viciifolia Scop.) on the in vitro larval migration of Haemonchus contortus: role of tannins and flavonol glycosides. J. Parasitol., 131, 531-538.

Brunet, S., Hoste, H. 2006. Monomers of condensed tannins affect the larval exsheathment of parasitic nematodes of ruminants. J. Agric. Food Chem., 54(20), 7481-7487.

Brunet, S., Aufrere, J., El Babili, F., Fouraste, I., Hoste, H. 2007. The kinetics of exsheathment of infective nematode larvae is disturbed in the presence of a tanninrich plant xtract (sainfoin) both in vitro and in vivo. J. Parasitol., 134, 1253-1262.

Darwis, W., Makda, R., Kasrina. 2013. Uji efektivitas ekstrak daun Iler-Iler (Coleus scutellarioides (Linn.) Benth) sebagai antibakteri Staphylococcus aureus. Konservasi Hayati, 9(2), 55-59.

He, S., Tiuria, R., Retnani, E.B. 1992. Uji biologis aktivitas anthelmintik sari buah nanas muda, daun miana dan ranting puring terhadap cacing Aspiculuris tetrapetra (Nematoda) dan Hymenolepis nana pada mencit putih (Mus musculus albinus). Hemera Zoa, 75, 94-110.

Hidayah, N. 2016. Pemanfaatan senyawa metabolit sekunder tanaman (tanin dan saponin) dalam mengurangi emisi metan ternak ruminansia. JSPI, 11(2), 89-98.

Ji, J., Lu, C., Kang, Y., Wang, G., Chen, P. 2012. Screening of 42 medicinal plants for in vivo anthelmintic activity against Dactylogyrus intermedius (Monogenea) in goldfish (Carassius auratus). Parasitol Res., 111, 97-104.
Karo, M., Hatta, M., Salma, W., Patellongi, I., Natzir, R. 2018. Effect of miana (Coleus scutellariodes (L) Benth) to expression of mRNA IL-37 in Balb/c mice infected Candida albicans. Phcog. J., 10(1), 16-19.

Khotimah, H., Risna, A., Mirhansyah, A. 2018. Pengaruh lama penyimpanan terhadap aktivitas antioksidan ekstrak daun miana (Coleus atropurpureus L. Benth). Samarinda, Indonesia, 20-21 Nov 2018.

Kusumawati, D.E., Pasaribu, F.H., Bintang, M. 2014. Aktivitas antibakteri isolat bakteri endofit dari tanaman miana (Coleus scutellariodes [L.] Benth.) terhadap Staphylococcus aureus dan Escherichia coli. Curr. Biochem., 1(1), 45-50.

Lee, Y.K., Kawasaki, I., Lim, Y., Oh, W.S., Paik, Y.K., Shim, Y,H. 2008. Inhibition developmental processes by flavon in Caenorhabditis elegans and its application to the pinewood nematode, Bursaphelenchus xylophilus. Mol. Cells., 26, 171-174.

Lohombo-Ekomba, M.L., Okusa, P.N., Penge, O., Kabongo, C., Choudhary, M.I., Kasende, O.E. 2004. Antibacteri, antifungal, antiplasmodial, and cytotoxic activities of Albertisia vilosa. J. Ethnopharmacol, 93, 331-335.

Masrifa, Saiful, A.L., Lenny. 2018. Uji Aktivitas Antelmintik Ekstrak Etanol Daun Ekor Naga (Rhaphidophora pinnata (L.) Schott) Secara in Vitro. Talenta Conf. Series: Trop. Med., 1(3), 90-94

Maulidya, D.A., Kahtan, M.I., Widiyantoro, A. 2017. Daya antelmintik ekstrak etanol daun kesum (Polygonum minus) terhadap Ascaridia galli secara in vitro. J. Cerebellum, 3(1), 731-740.

Meshnick, S.R., Tsang, T.W., Lin, F.B. 1989. Activated oxygen mediates the 
antimalarial activity of qinghaosu. Prog. Clin. Biol. Res., 313, 95-104.

Molan, A.L., Waghorn, G.C., Min, B.R., McNabb, W.C. 2000. The effect of condensed tannins from seven herbages on Trichostrongylus colubriformis larval migration in vitro. Folia Parasitol., 47, 39.

Nadhilla, N.F. 2014. The activity of antibacterial agent of honey against Staphylococcus aureus. J. Majority, 3(7), 94-101.

Pakadang, S.R., Wahjuni, C.U., Notobroto, H.B., Winarni, D., Dwiyanti, R., Yadi, Sabir, M., Hatta, M. 2015. Immunomodulator potential of miana leaves (Coleus scutellorioide (L) Benth) in prevention of tubercullosis infection. AJMR, 3(4), 129.

Pallete, T, Hatta, M, As'ad, S, Alam, G. 2017. Effect of purple miana leaf (Coleus scutellorioide (L) Benth) from Tana Toraja District on IL-10 mRNA expression in mice induced Mycobacterium tubercullosis. IJSBAR, 34(1), 111-115.

Podungge, M.R., Salimi, T.K., Duengo, S. 2017. Isolasi dan uji aktivitas antioksidan senyawa flavonoid dari daun miana (Coleus scutelleroides Benth.). Entropi, 12(1), $67-74$.

Poncet-Legrand, C., Edelmann, A., Putaux, J.L., Cartalade, D., Sarni-Manchado, P., Vernhet, A. 2006. Poly (L-proline) interactions with flavan-3-ols units: influence of the molecular structure and the polyphenol/protein ratio. Food Hydrocolloids, 20, 687-697.

Purwanti, R., Susanti, R., Martuti, N.K.T. 2012. Pengaruh ekstrak jahe terhadap penurunan jumlah ektoparasit protozoa pada benih kerapu macan. J. Life Sci, 1(2), 70-77.
Ridwan, Y., Ayunina, J.Q. 2007. Fitokimia dan aktivitas biologi anti cestoda beberapa varietas miana (Coleus blumei. Benth). J. Protein, 14(1), 23-28.

Ridwan, Y., Satrija, F., Darusman, L.K., Handaryani, E. 2010 ${ }^{\mathrm{a}}$ Aktivitas anticestoda In vitro ekstrak daun miana (Coleus blumei Bent) terhadap cacing Hymenolepis microstoma: pengamatan mengunakan SEM. J. Med. Vet., 25, 126133.

Ridwan, Y., Satrija, F., Darusman, L.K., Handaryani, E. 2010 . Efektivitas anticestoda ekstrak daun miana (Coleus blumei Bent) terhadap cacing Hymenolepis microstoma pada mencit. Media Peternakan, 33(1), 6-11.

Spicher, M., Roethlisberger, C., Lany, C., Stadelmann, B., Keiser, J., Ortega-Mora, L.M., Gottstein, B., Hemphill, A. 2008. In vitro and in vivo treatments of Echinococcus protoscoleces and metacestodes with artemisinin and artemisinin derivates. Antimicrob. Agents Chemother., 52(9), 3447-3450.

Tandon, V., Das, B., Saha, N. 2003. Anthelmintic efficacy of Flemingia vestita (Fabaceae): effect of genisten on glycogen metabolism in the cestode, Raillietina echinobothrida. Parasitol. Int., 52, 179183.

Widiarso, B.P., Nurcahyo, W., Prastowo, J., Kurniasih. 2017. Potensi daun bambu sebagai agen anthelmetika pada ternak kambing. J. Politeknik Pembangunan Pertanian Yogyakarta-Magelang, 130-139.

Yuliana, Fatmawati, S. 2018. Senyawa metabolit sekunder dan aspek farmakologi Alocasia macrorrhizos. Akta Kimindo, 3(1), 141-158. 